\title{
Using Histological Staining Techniques to Improve Visualization and Interpretability of Tooth Cementum Annulation Analysis
}

\author{
Uso de Técnicas de Tinción Histológica para Mejorar la Visualización \\ y la Interpretación del Análisis de la Anulación del Cemento Dental
}

Bojan Petrovic ${ }^{1}$; Jelena Pantelinac'; Ivan Capo' ${ }^{1}$; Dejan Miljkovic ${ }^{1}$; Milan Popovic ${ }^{1}$; Kristina Penezic ${ }^{2}$ \& Sofija Stefanovic ${ }^{2,3}$ PETROVIC, B; PANTELINAC, J.; CAPO, I.; MILJKOVIC, D.; POPOVIC, M.; PENEZIC, K. \& STEFANOVIC, S. Using
histological staining techniques to improve visualization and interpretability of tooth cementum annulation analysis. Int. J. Morphol.,
39(1):216-221, 2020.

SUMMARY: The aim of the present study was to evaluate the effect of different staining techniques on applicability and accuracy of tooth cementum annulation (TCA) method. Nine decalcination techniques, 8 dehydration protocols and 8 different techniques were applied in 3 teeth from the persons of a known age. Black and white, and color images of histological sections were captured. An xray was taken of each tooth and they were photographed. Researchers were asked to observe both black/white and color images of histological sections. Researchers were divided into two groups. The first group analyzed histological images only, and the second group had photos of teeth and X-rays. In the first group of observers (without X ray) the differences in age estimation between real and observed age were significant for 2 younger patients, but not for the oldest patient, where the observed and real values matched. Of the 6 raters, the assesments of the last 3 (that used x-ray images together with histological sections) did not differ significantly from the real values. Extensive analysis and multiple repetitions performed in the present investigation revealed that the most optimal method of decalcification for TCA method was EDTA II for a period longer than 14 days at a section thickness of 2-3mm, while the most optimal protocol for dehydration was number IV. When it comes to staining, the most optimal staining protocol used for the cemental lines visualization and counting was Crocein Scarlet/Acid Fuchsin staining and Toluidine blue staining used at semithin section. Additional use of preexperimental evaluation employing x-ray of analyzed teeth decreased the errors of age estimation.

KEY WORDS : Dental cementum; Increment lines; Age estimation.

\section{INTRODUCTION}

Dental cementum is the least understood of all the mineralized tissues (Bojarun et al., 2003; Kohli et al., 2013). It is divided into acellular and cellular cementum, depending on the presence of cementocytes. Acellular cementum is located adjacent to the dentinal surface, from the cervical margin to the cervical half, while the distribution of the cellular cementum is from the apical half to two thirds to the apical portion of the tooth root and furcation area. Both cellular and acellular cementum are irregularly distributed, however, cellular cementum usually covers acellular whith cementoblasts persisting in the periodontal ligament during the entire individual's life (Yamamoto et al., 2009). Formation of the tooth cementum takes place in a periodical rhythm, which leads to alterations in mineral crystal orientation (Lieberman \& Meadow, 1992). This can be seen as alternating dark and bright layers of cementum in microscopic images. One of the greatest advantages is that once cementum is formed, as a hard tissue in the body, it does not undergo alterations and is relatively stable even after long time post mortem (Wittwer-Backofen, 2012). Concentric lines are formed as cementum as a connective tissue, surrounds tooth roots in incremental layers. One year of life corresponds to each pair of lines (Gupta et al., 2014). In forensic anthropology, paleopathology and paleodemography, the estimation of an individual's age at death is very important issue when performing post mortem identification of human remains (Stott et al., 1982; Carrasco et al., 2014; Dias et al., 2010; Kasetty et al., 2010). Bones 
and teeth, as hard tissues, are capable to resist degradation and decay for much longer after soft tissues have disappeared. Tooth cementum annulation method, TCA can be used as very reliable age marker, hypothetically more reliable than any other histological or morphological trait in the human body. Often, teeth are the only means of identification. Calculation of the final age is done by adding the age of the root formation to the mean number of counted cementum layers, since forming of cementum begins after the root development. Different studies report different protocols and errors for the described method for age determination (Gauthier \& Schutkowski, 2013; Bertrand et al., 2019; Penezic' et al., 2019) so there is a need for the standardization of the procedure, that can be used within the anthropological, archeological, forensic and histological context.

\section{MATERIAL AND METHOD}

Standardization of treatment and histological dying were performed using individually designed set of preparation techniques. For the purposes of this project, samples of 3 teeth of persons of different ages $(15,28$ and 61 year-old females) were collected from the Dental Clinic of Vojvodina. The samples were cut with a circular saw in the transverse and longitudinal plane to cross sections about $1.5 \mathrm{~mm}$ thick. In the first phase of the study, an examination was made of adequate decalcination on tooth preparations. Nine different decalcinates (Table I) were tested for 7 and 14 days, respectively. After selecting adequately decalcified samples, the teeth were divided into two groups. Samples from the first group were treated with a standard histological tank, while those from the second were embedded in resin and cut into semi-thin cuts. Samples were first subjected to different dehydration protocols to extract water from the tissue to the best of its ability. After the dehydration process, the tissue was permeated with liquid paraffin for three hours, after which the samples were embedded and cut into into 5 $\mu \mathrm{m}$ thick sections. For the purpose of clear visualization of the incremental lines of cementum the following staining were used: standard histological Hematoxylin-Eosin staining (H\&E), Toluidine Blue (TB), Van Gieson, Mallory Trichrome, Masson Trichrome, Periocid Acid Shiff and Crocein Scarlet / Acid Fuchsin.

Table I. Decalcination and dehydratation protocols.

\begin{tabular}{|c|c|}
\hline \multicolumn{2}{|c|}{ Composition of decalcinates used in the study } \\
\hline DECALCINATE & COMPOSITION: substance (amount) \\
\hline $5 \%$ Formic acid & $\mathrm{ccHCOOH}(5 \mathrm{ml}), \mathrm{dH}_{2} \mathrm{O}(95 \mathrm{ml})$ \\
\hline $10 \%$ Formic acid & $\mathrm{ccHCOOH}(10 \mathrm{ml}), \mathrm{dH}_{2} \mathrm{O}(90 \mathrm{ml})$ \\
\hline $5 \%$ Nitric acid & $\mathrm{ccHNO}_{3}(5 \mathrm{ml}), \mathrm{dH}_{2} \mathrm{O}(95 \mathrm{ml})$ \\
\hline Miller solution & $\mathrm{K}_{2} \mathrm{Cr}_{2} \mathrm{O}_{7}(5 \mathrm{ml}), \mathrm{Na}_{2} \mathrm{SO}_{4}(10 \mathrm{~g}), \mathrm{dH}_{2} \mathrm{O}(75 \mathrm{ml})$ \\
\hline Evans \& Krajian & $\mathrm{ccHCOOH}(5 \mathrm{ml}), \mathrm{Na}_{2} \mathrm{C}_{6} \mathrm{H}_{5} \mathrm{O}_{7}(10 \mathrm{~g}), \mathrm{dH}_{2} \mathrm{O}(95 \mathrm{ml})$ \\
\hline Gooding and Stewart & $\mathrm{ccHCOOH}(5 \mathrm{ml}), 40 \%$ Formaldehyde $(5 \mathrm{ml}), \mathrm{dH}, \mathrm{O}(95 \mathrm{ml})$ \\
\hline EDTA I & EDTA $(2 \mathrm{~g}), \mathrm{dH}_{2} \mathrm{O}(20 \mathrm{ml})$, Tris Base $(2.5 \mathrm{~g})$ \\
\hline EDTA II & EDTA $(2.5 \mathrm{~g}), \mathrm{dH}_{2} \mathrm{O}(17.5 \mathrm{ml}), \mathrm{NaOH}(1 \mathrm{~g})$ \\
\hline Formaldehyde: Fromic acid $(1: 1)$ & $40 \%$ Formaldehyde $(50 \mathrm{ml}), 30 \% \mathrm{ccHCOOH}(50 \mathrm{ml})$ \\
\hline \multicolumn{2}{|c|}{ Protocols for dehydration of tooth sample } \\
\hline DESIGNATION & Protocol Solution (time, repetition) \\
\hline DEHYDRATION I & $\begin{array}{l}70 \% \mathrm{E} \text { tOH }(1 \mathrm{~h}, 2 \mathrm{x}), 80 \% \mathrm{E} \text { tOH }(1 \mathrm{~h}, 2 \mathrm{x}), 100 \% \text { Isopropanol }(1 \mathrm{~h}, 1 \mathrm{x}) \text {, Clearing - } \\
\text { Xylol/Chloroform }(30 \mathrm{~min}, 1 \mathrm{x})\end{array}$ \\
\hline DEHYDRATION II & $\begin{array}{l}50 \% \text { EtOH }(1 \mathrm{~h}, 2 \mathrm{x}), 70 \% \text { EtOH }(1 \mathrm{~h}, 2 \mathrm{x}), 80 \% \mathrm{EtOH}(1 \mathrm{~h}, 2 \mathrm{x}), 90 \% \mathrm{EtOH}(1 \mathrm{~h}, 2 \mathrm{x}), 100 \% \\
\text { EtOH }(1 \mathrm{~h}, 3 \mathrm{x}) \text {, Clearing - Xylol/Chloroform (30 min, 1x), Xylol : Paraffin (1:1) (30 min, 1x), } \\
\text { Paraffin (30min, 3x) }\end{array}$ \\
\hline DEHYDRATION III & $\begin{array}{l}70 \% \text { EtOH }(1 \mathrm{~h}, 1 \mathrm{x}), 95 \% \mathrm{EtOH}(1 \mathrm{~h}, 3 \mathrm{x}), 100 \% \mathrm{EtOH}(1 \mathrm{~h}, 2 \mathrm{x}), \text { Clearing - Xylol/Chloroform } \\
(30 \mathrm{~min}, 2 \mathrm{x})\end{array}$ \\
\hline DEHYDRATION IV & $\begin{array}{l}70 \% \text { EtOH }(12 \mathrm{~h}, 1 \mathrm{x}), 96 \% \mathrm{EtOH}(1 \mathrm{~h}, 3 \mathrm{x}), 100 \% \mathrm{EtOH}(1 \mathrm{~h}, 2 \mathrm{x}) \text {, Clearing - Xylol/Chloroform } \\
(30 \mathrm{~min}, 1 \mathrm{x})\end{array}$ \\
\hline DEHYDRATION V & $\begin{array}{l}60 \% \mathrm{EtOH}(12 \mathrm{~h}, 1 \mathrm{x}), 70 \% \mathrm{EtOH}(30 \mathrm{~min}, 1 \mathrm{x}), 80 \% \mathrm{EtOH}(30 \mathrm{~min}, 1 \mathrm{x}), 95 \% \text { EtOH }(30 \mathrm{~min}, \\
1 \mathrm{x}), 100 \% \mathrm{EtOH}(22 \mathrm{~min}, 3 \mathrm{x}) \text {, Clearing - Xylol/Chloroform }(30 \mathrm{~min}, 1 \mathrm{x})\end{array}$ \\
\hline DEHYDRATION VI & $\begin{array}{l}70 \% \text { I sopropanol }(12 \mathrm{~h}, 1 \mathrm{x}), 80 \% \text { Is opropanol }(1 \mathrm{~h}, 1 \mathrm{x}), 96 \% \text { Isopropanol }(1 \mathrm{~h}, 1 \mathrm{x}), 100 \% \\
\text { Isopropanol }(1 \mathrm{~h}, 1 \mathrm{x})\end{array}$ \\
\hline DEHYDRATION VII & $\begin{array}{l}70 \% \text { Isopropanol }(1 \mathrm{~h}, 1 \mathrm{x}), 80 \% \text { Isopropanol }(1 \mathrm{~h}, 1 \mathrm{x}), 96 \% \text { Isopropanol }(1 \mathrm{~h}, 1 \mathrm{x}), 100 \% \\
\text { Isopropanol }(1 \mathrm{~h}-1 \mathrm{x})\end{array}$ \\
\hline DEHYDRATION VIII & $\begin{array}{l}50 \% \text { Acetone }(1 \mathrm{~h}, 1 \mathrm{x}), 70 \% \text { Acetone }(1 \mathrm{~h}, 1 \mathrm{x}), 90 \% \text { Acetone }(1 \mathrm{~h}, 1 \mathrm{x}), 96 \% \text { Acetone }(1 \mathrm{~h}, 1 \mathrm{x}) \text {, } \\
100 \% \text { Acetone }(1 \mathrm{~h}, 1 \mathrm{x}) \text {, Clearing - Xylol/Chloroform }(30 \mathrm{~min}, 1 \mathrm{x})\end{array}$ \\
\hline
\end{tabular}


The remaining material was treated as follows: After decalcification, the tooth samples were cut into pieces of approximate size $1 \mathrm{~mm} 3$. The samples were then fixed for 2 $\mathrm{h}$ in $1 \%$ osmium tetraoxide dissolved in $0.1 \mathrm{M} \mathrm{Na}$-cacodylate buffer in the refrigerator at $4{ }^{\circ} \mathrm{C}$. They were then washed and transferred to a $4 \%$ aqueous solution of uranyl acetate for $1 \mathrm{~h}$. The samples were washed 3 times with distilled water, and dehydrated with increasing concentrations of acetone according to the protocol presented in Table I. After dehydration, the tissue was embedded in epoxy resin and allowed to resin polymerize for $48 \mathrm{~h}$ at $60{ }^{\circ} \mathrm{C}$. The molds were then cut on an ultramicrotome using glass knives into sections of about $1 \mu \mathrm{m}$ thickness. The sections obtained were stained with toluidine blue staining and viewed under a light microscope. Black and white, and color images of histological sections were captured. An x-ray was taken of each tooth and they were photographed. Researchers were asked to observe both black/white and color images of histological sections. Researchers were divided into two groups. The first group analyzed histological images only, and the second group had photos of teeth and X-rays. The researchers were allowed to decide whether to estimate the number of lines on one, two or more images. The requirement was to enter a minimum of three counts in the spreadsheet. Consistency between multiple researchers was measured by the degree of inter-rater agreement.
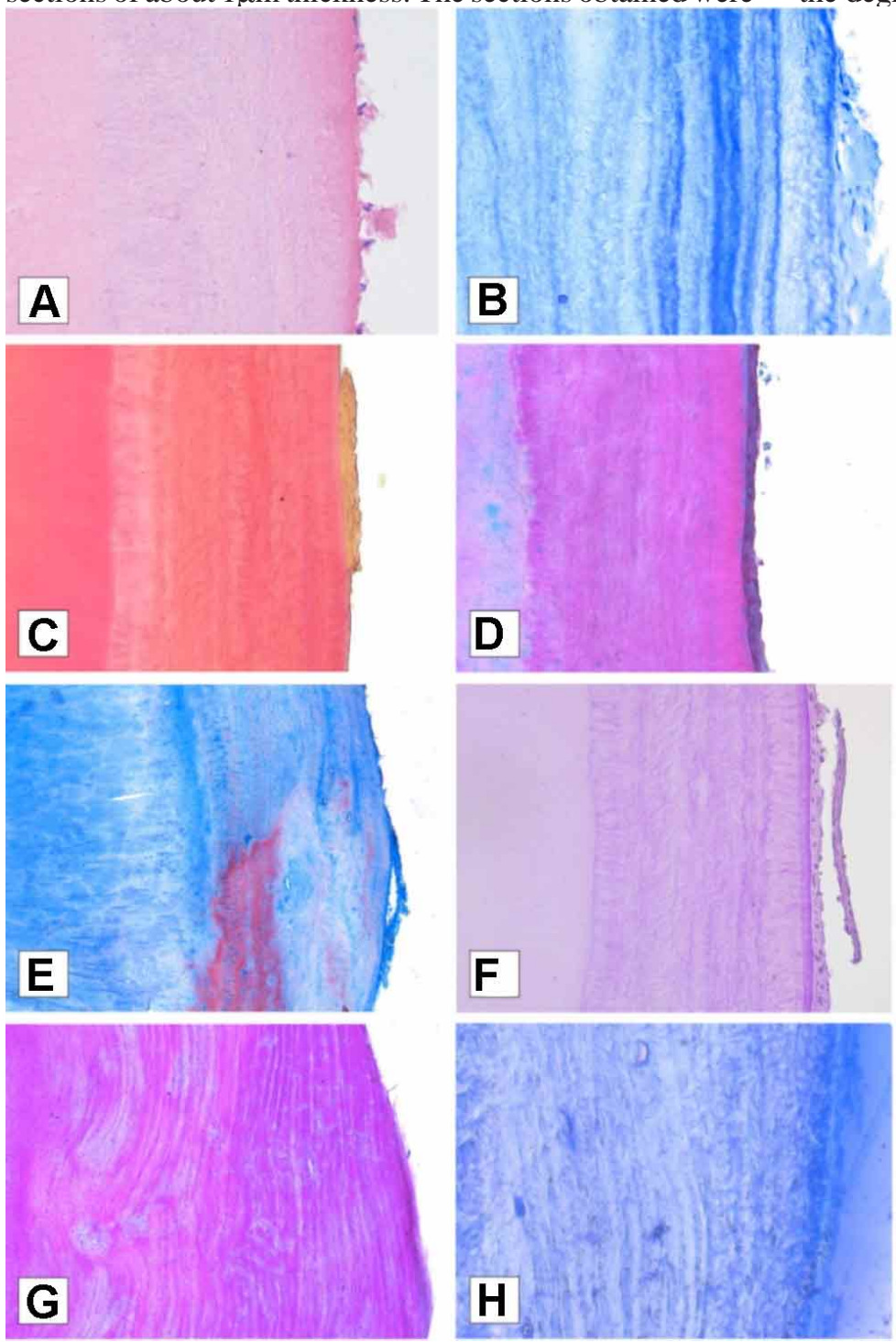

Fig. 1. Different histochemical staining of cement within the tooth root: a) Hematoxyline \& Eosin staining; b) Toluidine blue staining at standard cross section; c) Van Gieson staining; d) Masson Trichrome staining; e) Mallory Trichrome; f) Periodic Acid Schiff staining; g) Crocein Scarlet / Acid Fuchsin staining; h) Toluidine blue staining at semi-thin section.

\section{RESULTS}

Regarding the staining techniques following observations were reported by the evaluators: in the slices stained with H\&E (Fig. 1a), dentinocemental line was not clear, and it was difficult to assign where to start counting (Fig. 2), the cemental lines were not visible. In the slice stained with TB on standard sections (b), incremental lines of cementum were not visible, and the appearance of the cementodentinal junction wasn't clear. Van Gieson staining (c) showed that cementodentinal junction wasn't clear, incremental lines were blurry, so it was complicated to count them. In the slices stained with Masson Trichrome staining (d), cemental lines were faint, hard to count, but cementodentinal junction was bright and clear. Mallory Trichrome (e) exhibited incremental lines undefined and foggy, while dentinocemental line was evident. In the sections stained with Periodic Acid Schiff (f), cementodentinal junction was detectable, incremental lines are shadowy but possible to count. Crocein Scarlet/ Acid Fuchsin (g) staining technique caused that cemental lines were clear and easy to count, however cementodentinal junction was not that pronounced and in the last section, stained with Toluidine blue (h), dentinocemental line was recognizable and incremental lines were distinct and simple to count. Two slices that were found the most observable and easiest to count were the last two, stained with Crocein Scarlet/ Acid Fuchsin and Toluidine blue on semi-thin section. 


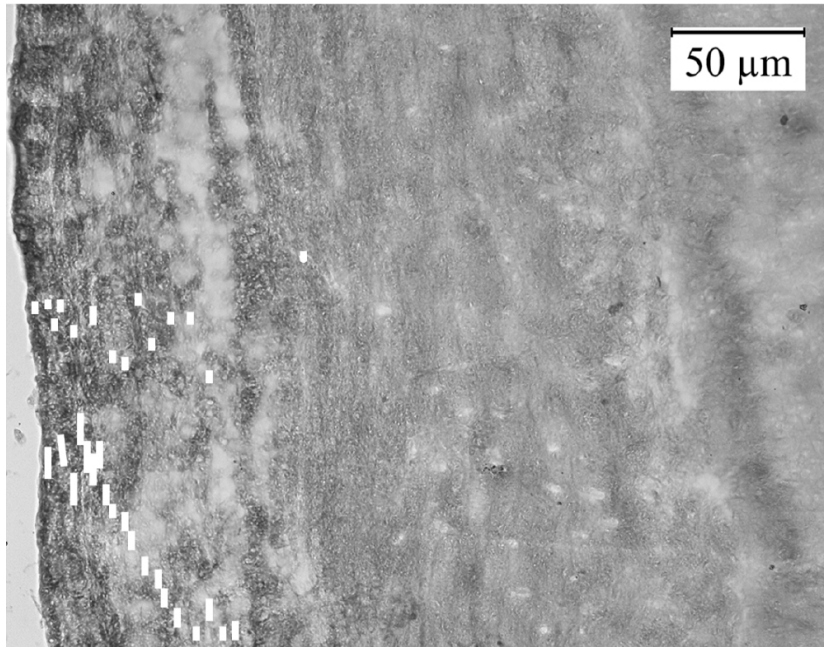

Fig. 2. Cemental line counting.
There was generally no agreement among raters when looking at individual patient/ tooth (Table II). For analyzing the differences between observed and real age of patients/ teeth, a parametric t-test for dependent samples was applied. The differences were significant for patients 1 and 2, but not for patient 3 , where the observed and real values matched. Of the 6 raters, the assessments of the last 3 (that used x-ray images together with histological sections) did not differ significantly from the real values.

Table II. Differences between observed and real age and by rates.

\begin{tabular}{|c|c|c|c|c|c|c|c|c|}
\hline \multicolumn{9}{|c|}{ Differences between observed and real age by patients } \\
\hline & Mraters & Mreal & $\mathrm{t}(4)$ & $\mathrm{P}$ & Mean & SE Mean & SD & ICC $(95 \% \mathrm{CI})$ \\
\hline S 1 & 17.37 & 5 & 44.83 & .000 & 13.37 & 0.28 & 0.62 & $-.01(-.02-.07)$ \\
\hline S 2 & 24.77 & 15 & 11.66 & .000 & 9.77 & 0.84 & 1.87 & $-.05(-.15-.46)$ \\
\hline S 3 & 55.27 & 55 & 0.36 & $.736^{*}$ & 0.27 & 0.74 & 1.65 & $0.21(-.25-.84)$ \\
\hline Total & 32.47 & 25 & 5.21 & .000 & 7.47 & 1.43 & 5.56 & $0.92(-.75-.97)^{*}$ \\
\hline \multicolumn{9}{|c|}{ Differences between observed and real age by raters } \\
\hline & Mraters & Mreal & $\mathrm{t}(14)$ & $\mathrm{P}$ & Mean & SE Mean & SD & \\
\hline $\mathrm{Ob} 1$ & 46.33 & 25 & 7.15 & .00 & 21.33 & 2.98 & 11.55 & \\
\hline $\mathrm{Ob} 2$ & 45.20 & 25 & 4.77 & .00 & 20.20 & 4.24 & 16.41 & \\
\hline $\mathrm{Ob} 3$ & 28.47 & 25 & 3.77 & .00 & 3.47 & 0.92 & 3.56 & \\
\hline $\mathrm{Ob} 4$ & 23.93 & 25 & -1.44 & $.17 *$ & -1.07 & 0.74 & 2.87 & \\
\hline Ob 5 & 26.67 & 25 & 1.86 & $.09^{*}$ & 1.67 & 0.90 & 3.48 & \\
\hline Ob 6 & 24.20 & 25 & $-1,23$ & $.24 *$ & -0.80 & 0.65 & 2.51 & \\
\hline
\end{tabular}

ICC $=$ two-way random, absolute agreement, $\mathrm{CI}=$ confidence interval .

\section{DISCUSSION}

Imaging methods used for examining cementum annulation include various types of microscopic techniques including light microscopy, scanning and transmission electron microscopy, phase-contrast microscopy and computerized tomography (Foster, 2012). At the same time, controlled human clinical studies have rarely been used to confirm the applicability and the accuracy of the method. Additionally, cementum investigation is significantly weighed down by an over-emphasis on optical microscopy as observed by Naji et al. (2016), while the combination of the clinical, macroscopic and radiographic methods together with histological techniques is rarely reported. In the present investigation various staining techniques, as described by Foster in the comprehensive analysis as "promising" for visualizing cementum under light microscopy were used in order to evaluate their perks such as making contrast between cementum and alveolar bone, features of the distinction between mineralized and non-mineralized structures, hypercementosis, reparatory processes etc. In addition, the effect of clinical/radiographic assessment on observers' accuracy has been evaluated. H\&E staining is the most common differential stain for histological sections, and is widely used in other applications such as pathology biopsies to provide contrast to colorless cells and tissues for the purpose of studying morphology. In the present investigation H\&E staining did not provide adequate contrast between cementum and the underlying dentin making lines counting difficult. TB is also a basic dye that provided limited advantages in standard sections, with cementum stained a dark blue, distinct from the whitish color of the dentin, but 
evident improvement in semithin sections. Kvaal et al. (1996) suggested that Periodic acid Schiff staining are applicable for visualization of the cementum incremental lines. The results from the present investigation could not confirm these findings, since despite the fact that cementodentinal junction was clearly visible, the contrast required for line counting was not sufficient. Percival \& Radi (2017) emphasized the potential of Van Gieson staining for remarkable selectivity for elastic tissues. Unfortunately, observers in the present investigation found it difficult for TCA method. Similarly, Abrahão et al. (2006) successfully used Masson's Trichrome staining for dental development evaluation, but in the present investigation line counting had been hampered due to lack of sharpness between 2 consecutive cemental lines. In the same way Leonardo et al. (1998) described the use of Mallory trichrome staining for analysis of root canal fillings, but our observations revealed that despite the clear and bright cementodentinal junction, the appearance of incremental line was to some extent foggy. Chen et al. (2018) reported the use of crocein scarlet staining in the evaluation of the osteoblast activity. The results from the present investigation go in line with its potential use in TCA method since the observers reported no difficulties in cemental lines visualization. Generally, the comparison of multiple histological staining revealed that while frequently applied stains offer adequate results to some extent and for some features, these are not necessarily optimal for cemental lines visualization and lines counting. Regarding the decalcination methods the results from the present investigation go in line that the most optimal method was EDTA II for a period longer than 14 days at a section thickness of 2-3mm, while the most applicable dehydratation protocol was number 4 as described in details in Table I.

It has been suggested that various approaches including improved individual experience and enhanced experimental design could provide better control of possible errors in TCA method (Naji et al.). In the present investigation, half of the observers analyzed the images along with the $\mathrm{x}$-ray images of the teeth, and it turned out that it significantly decreased the errors in age estimation. According to the results from the present investigation, the combination of macroscopic, clinical, radiographic methods, before the teeth are cut could improve the applicability and accuracy of the TCA method and help avoid inaccurate age at death estimations, which be problematic for forensic and archeological requirements (Renz \& Radlanski, 2006).

Extensive analysis and multiple repetitions performed in the present investigation revealed that the most optimal method of decalcification for TCA method was EDTA II for a period longer than 14 days at a section thickness of 2$3 \mathrm{~mm}$, while the most optimal protocol for dehydration was number IV. When it comes to staining, the most optimal staining protocol used for the cemental lines visualization and counting was Crocein Scarlet/Acid Fuchsin staining and Toluidine blue staining used at semithin section. Additional use of pre-experimental evaluation employing x-ray of analyzed teeth decreased the errors of age estimation.

PETROVIC, B; PANTELINAC, J.; CAPO, I.; MILJKOVIC, D.; POPOVIC, M.; PENEZIC, K. \& STEFANOVIC, S.Uso de técnicas de tinción histológica para mejorar la visualización y la interpretación del análisis de la anulación del cemento dental. Int. J. Morphol., 39(1):216-221, 2020.

RESUMEN: El objetivo del presente estudio fue evaluar el efecto de diferentes técnicas de tinción sobre la aplicación y precisión del método de anulación de cemento dental (TCA). Se usaron nueve técnicas de descalcinación, 8 protocolos de deshidratación y 8 técnicas diferentes en 3 dientes de personas de edad conocida. Se capturaron imágenes en blanco y negro y en color de cortes histológicos. Se tomó una radiografía de cada diente y se fotografiaron. Los investigadores observaron las imágenes en blanco y negro y en color de las secciones histológicas. Los investigadores se dividieron en dos grupos; el primer grupo analizó solo imágenes histológicas y el segundo grupo tenía fotografías de los dientes y las radiografías. En el primer grupo de observadores (sin rayos X) las diferencias en la estimación de la edad entre la edad real y la edad observada fueron significativas para 2 pacientes más jóvenes, pero no para el paciente de mayor edad, donde los valores observados y reales coincidieron. De los 6 evaluadores, las valoraciones de los 3 últimos (que utilizaron imágenes de rayos $\mathrm{X}$ junto con cortes histológicos) no difirieron significativamente de los valores reales. El análisis exhaustivo y las múltiples repeticiones realizadas en la presente investigación revelaron que el método de descalcificación más óptimo para el método TCA fue EDTA II durante un período superior a 14 días con un grosor de sección de 2-3 mm, mientras que el protocolo óptimo para la deshidratación fue el número IV . En lo que respecta a la tinción, el protocolo de tinción más óptimo utilizado para la visualización y el recuento de las líneas de cemento fue la tinción con croceína escarlata / fucsina ácida y la tinción con azul de toluidina utilizada en la sección semifina. El uso adicional de la evaluación pre-experimental que emplea los rayos X de los dientes analizados disminuyó los errores de estimación de la edad.

PALABRAS CLAVE: Cemento dental; Incrementar líneas; Estimación de edad.

\section{REFERENCES}

Abrahão, I. J.; Martins, M. D.; Katayama, E.; Antoniazzi, J. H.; Segmentilli, A. \& Marques, M. M. Collagen analysis in human tooth germ papillae. Braz. Dent. J., 17(3):208-12, 2006.

Bertrand, B.; Cunha, E.; Bécart, A., Gosset, D. \& Hédouin, V. Age at death estimation by cementochronology: Too precise to be true or too precise to be accurate? Am. J. Phys. Anthropol., 169(3):464-81, 2019. 
PETrovic, B; PANTElinAC, J.; CAPO, I.; MILJKOVIC, D.; POPOVIC, M.; PENEZIC, K. \& STEFANOVIC, S. Using histological staining techniques to improve visualization and interpretability of tooth cementum annulation analysis. Int. J. Morphol., 39(1):216-221, 2020.

Bojarun, R.; Garmus, A. \& Jankauskas, R. Microstructure of dental cementum and individual biological age estimation. Medicina (Kaunas), 39(10):960-4, 2003.

Carrasco, T. P.; González, S. J.; Brizuela, C. C. \& Inostroza, S. C. Legal medical age estimation using two methods measuring root dentin translucency: comparative analysis. Int. J. Morphol., 32(3):956-61, 2014.

Chen, C. H.; Wang, L.; Tulu, U. S.; Arioka, M.; Moghim, M. M.; Salmon, B.; Chen, C. T.; Hoffman, W.; Gilgenbach, J.; Brunski, J. B.; et al. An osteopenic/osteoporotic phenotype delays alveolar bone repair. Bone, 112:212-9, 2018.

Dias, P. E. M.; Beaini, T. L. \& Melani, R. F. H. Age estimation from dental cementum incremental lines and periodontal disease. J. Forensic Odontostomatol., 28(1):13-21, 2010.

Foster, B. L. Methods for studying tooth root cementum by light microscopy. Int. J. Oral Sci., 4(3):119-28, 2012.

Gauthier, J. \& Schutkowski, H. Assessing the application of tooth cementum annulation relative to macroscopic aging techniques in an archeological sample. Homo, 64(1):42-57, 2013.

Gupta, P.; Kaur, H.; Madhu Shankari, G. S.; Jawanda, M. K. \& Sahi, N. Human age estimation from tooth cementum and dentin. J. Clin. Diagn. Res., 8(4):ZC07-10, 2014.

Kasetty, S.; Rammanohar, M. \& Ragavendra, T. R. Dental cementum in age estimation: a polarized light and stereomicroscopic study. $J$. Forensic Sci., 55(3):779-83, 2010.

Kohli, A.; Pezzotto, S. M. \& Poletto, L. Normal human dental roots and with cementum pearls. structural histological comparison. Int. J. Morphol., 31(3):1020-5, 2013.

Kvaal, S. I.; Solheim, T. \& Bjerketvedt, D. Evaluation of preparation, staining and microscopic techniques for counting incremental lines in cementum of human teeth. Biotech. Histochem., 71(4):165-72, 1996.

Leonardo, M. R.; Almeida, W. A.; da Silva, L. A. \& Utrilla, L. S. Histological evaluation of the response of apical tissues to glass ionomer and zinc oxide-eugenol based sealers in dog teeth after root canal treatment. Endod. Dent. Traumatol., 14(6):257-61, 1998.

Lieberman, D. E. \& Meadow, R. H. The biology of cementum increments (with an archaeological application). Mammal Rev., 22(2):57-77, 1992.

Naji, S.; Colard, T.; Blondiaux, J.; Bertrand, B.; d'Incau, E. \& BocquetAppel, J. P. Cementochronology, to cut or not to cut? Int. J. Paleopathol., 15:113-9, 2016.

Penezic, K.; Porcic, M.; Jovanovic, J.; Urban, P. K.; Wittwer-Backofen, U. \& Stefanovic', S. Quantifying prehistoric physiological stress using the TCA method: Preliminary results from the Central Balkans. Doc. Praehist., 46:284-95, 2019.

Percival, K. \& Radi, Z. Comparison of five elastin histochemical stains to identify pulmonary small vasculature. J. Histotechnol., 40(3):73-8, 2017.

Renz, H. \& Radlanski, R. J. Incremental lines in root cementum of human teeth--a reliable age marker? Homo, 57(1):29-50, 2006.

Stott, G. G.; Sis, R. F. \& Levy, B. M. Cemental annulation as an age criterion in forensic dentistry. J. Dent. Res., 61(6):814-7, 1982.

Wittwer-Backofen, U. Age estimation using tooth cementum annulation. In Forensic Microscopy for Skeletal Tissues. Totowa, Humana Press, 2012. pp.129-43.

Yamamoto, H.; Niimi, T.; Yokota-Ohta, R.; Suzuki, K.; Sakae, T. \& Kozawa, Y. Diversity of acellular and cellular cementum distribution in human permanent teeth. J. Hard Tissue Biol., 18(1):40-4, 2009.

\section{Corresponding author: \\ Bojan Petrovic \\ University of Novi Sad \\ Faculty of Medicine \\ Department for Dentistry \\ Hajduk Veljkova 3 \\ 21000 Novi Sad \\ SERBIA}

Email: bojan.petrovic@mf.uns.ac.rs

Received: 05-08-2020

Accepted: 10-09-2020 